\title{
ENTREPRENEURIAL INTENTIONS OF RESEARCH SCIENTISTS AND ENGINEERS
}

\author{
J. Chantson ${ }^{1} \&$ B. Urban ${ }^{1 *}$
}

\section{ARTICLE INFO}

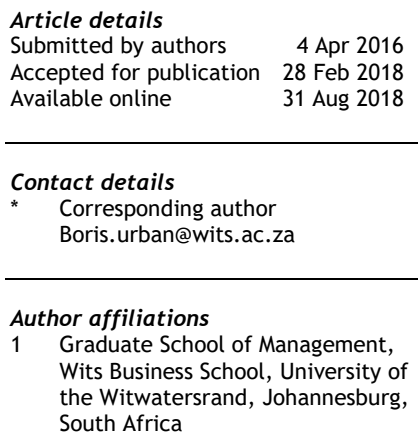

DOI

http://dx.doi.org/10.7166/29-2-1533

\section{ABSTRACT}

Recognising the importance of the commercialisation of university intellectual property, the entrepreneurial intentions (EI) of research scientists and engineers at universities and science councils in South Africa are investigated. The study of intentions in an academic context has been recognised because of the potential of entrepreneurship to ignite new research knowledge. Following hypothesis testing, the results show that the El antecedents of attitudes towards behaviour, social norms, and perceived behavioural control need to be treated systematically. By integrating these factors into one cohesive framework, policy makers may better understand the complexity of the antecedents involved in enhancing El.

\section{OPSOMMING}

Om erkenning te gee vir die belangrikheid van die kommersialisering van intellektuele eiendom binne 'n universiteit word die entrepreneur-intensies van navorsers (wetenskaplikes en ingenieurs) by universiteite en wetenskaprade in Suid-Afrika ondersoek. Die studie van dié intensies in 'n akademiese konteks is van belang as gevolg van die potensiaal van entrepreneurskap om nuwe navorsingskennis aan te hits. Na hipotesetoetsing toon die resultate dat die voorlopers van entrepreneurintensies, soos gedrag, sosiale norme en waargeneemde gedragsbeheer, sistemies hanteer moet word. Deur hierdie faktore in een samehangende netwerk te integreer mag besluitnemers lei om die kompleksiteit van die voorlopers van entrepreneurintensies beter te verstaan.

\section{INTRODUCTION}

The African Union prioritises science, technology, and innovation (STI) as a catalyst for Africa's development in the next 50 years, thereby placing STI at the centre of its development discourse [1]. In South Africa (SA), the Intellectual Property Rights (IPR) Act was enacted in August 2010 to facilitate the commercialisation of publicly funded research and development [1]. Correspondingly, the Department of Science and Technology (DST) fostered a National System of Innovation (NSI) through a number of policy interventions [2]. As a result of such initiatives, more universities have established technology transfer offices for the purposes of increasing the commercialisation of university intellectual property $[3,4,5]$. It is increasingly recognised that academics need to be entrepreneurial to be successful in research, teaching, engagement in practice $[6,7]$, and the commercialisation of academic knowledge $[8,9]$.

However, a critical reading of the literature finds that SA is not a particularly efficient innovator in converting innovation inputs into outputs. Despite the research funding allocated to universities and public research organisations or science councils, only a small percentage of research outputs are commercialised in SA [10, 11]. The support provided by technology transfer offices generally concentrates on the identification and protection of new intellectual property, with much less focus on start-up formation [3,7]. Additionally, not only is there a poor or lack of awareness and understanding of the technology innovation process in SA - including the commercialisation of inventions [10] - but the low rate of start-ups in South Africa has been attributed to many 
institutions' preference for licensing to established companies. This situation is further exacerbated by a lack of entrepreneurially orientated researcher scientists and engineers who are prepared to leave academia to start a business based on their research [12, 13].

Along with the increasing importance of research commercialisation and the emergence of the concept of the 'entrepreneurial university' [8], the body of literature dedicated to university spinouts and start-ups has grown over recent years [14]. While the majority of existing studies have adopted a contextual perspective in which the role of the university or the local environment is examined, the role of the academic scientist or researcher as an agent in the entrepreneurial process is often neglected $[8,15]$. Recognising this gap in the literature, and acknowledging that to be an agent is to make things happen intentionally by one's own actions [16], this purpose of this study is to examine the entrepreneurial intentions (EI) of research scientists and engineers at universities and science councils in SA. The study of intentions in an academic context has been acknowledged, given the potential of entrepreneurship to ignite new research knowledge [17].

This study provides the following contributions to existing knowledge on intentions in the context of academic entrepreneurship. First, it adds to the literature by providing causal links between the distal factors and antecedents of El. Rather than merely testing the antecedents of El, a more nuanced approach is adopted to show how different variables operate through different pathways, or vary in the strength of the paths through which they operate. Second, the study takes place in an under-researched country, SA, where understanding the role that perceived barriers and support mechanisms play in shaping El could prove valuable. Third, the study has implications for scientists, academics, engineers, and policy makers who need to take into account factors that may influence the antecedents of intentions to increase overall El. By acknowledging that universities and research organisations strive to contribute to regional economic development through adopting a culture of entrepreneurship [18, 19], the study contributes to a better understanding of the role of academic entrepreneurship.

\section{ACADEMIC ENTREPRENEURSHIP}

Academic entrepreneurship simply means the creation of new business ventures by any of a university's agents [20], and is often used in conjunction with the term 'scientist entrepreneurship' [21], where the focus is on an individual scientist or engineer who typically starts a new technology firm [22]. Research finds that organisational characteristics - both climate and culture - within and around the university affect research scientists' and academics' propensity to engage in entrepreneurial activity [23]. These support factors include management and peer support, organisational innovation orientation, compatibility of patenting with publishing, incentives for engagement in commercialisation activities, opportunities for networking, and interactions with industry and alliances with established firms [24, 25]. Appreciating that entrepreneurship is the mechanism through which knowledge is converted into innovation outcomes [26]), practices such as the entrepreneur-in-residence concept have been introduced at the Council for Scientific and Industrial Research (CSIR) in SA [27]. Similarly, university policies, and the incentives they offer, are often employed to transform academics' behaviour [28]. Such policies have been found to serve as a knowledge filter of academics' start-up intentions indirectly through motivational factors [29, 23]. Additionally, the undertaking of applied research by research institutes has been found to mediate the positive relationship between an academic researcher's cooperation with industry and his/her EI [30].

The importance of close ties to industry has been emphasised in a number of academic entrepreneurship studies [31, 32]. Several studies indicate that networking allows entrepreneurs to enlarge their knowledge of opportunities, to gain access to critical resources, and to deal with business obstacles [33, 34, 15]. It has also been noted that academics who are overly focused on the scientific aspects of their start-up idea tend to pursue their idea in a sub-optimal way, as they have limited business knowledge, industrial experience [35], or entrepreneurial experience [36, 32]. A number of recommendations have been made for how technology transfer offices can support academic entrepreneurs, such as connecting the university-based founders to experienced entrepreneurs from outside the university, and helping them find suitable team members to join the start-up [37].

On the other hand, frequently cited institutional barriers to academic entrepreneurship include accessing capital markets, access to resources, the national intellectual property rights (IP) regime, 
and government regulations $[3,13,35,38]$. Not only does SA have a relatively small domestic market, especially for technology products, but large multi-national companies dominate its economy, where limited seed and early-stage funding is available for start-ups [39]. Similarly, government regulations and practices exert an influential role in how potential entrepreneurs perceive new opportunities and how market spaces can be created and eventually exploited [40]. SA's regulatory institutional environment does not make entrepreneurship a highly desirable career option; the pool of intentional entrepreneurs is well below the average for efficiency-driven countries, according to the Global Entrepreneurship Monitor (GEM) report [41].

The nature of the national IP regime can have a marked effect on innovation, technology transfer, commercialisation, and entrepreneurship [10,11]. Unlike many countries that have examining patenting systems, SA has a deposit or non-examining patent regime in place. This type of IP system creates an asymmetry disadvantage for SA inventors, thereby expediting exploitation by foreign interests and leading to increased social costs [42]. Additionally, certain provisions in the IPR Act have been negatively received by the private sector, with the unintended consequence that it has driven the private sector away from collaborating with publicly-funded research organisations, and so has negatively affected academic researchers' El.

\section{ENTREPRENEURIAL INTENTIONS}

Ajzen [43] conceptualises 'intention' as a person's readiness to perform a given behaviour. Across a wide range of different behaviours, behavioural intentions have been identified as the most immediate predictor of actual behaviour [44]. A number of studies have employed the theory of planned behaviour (TPB) to examine intention [45]. The TPB posits that, for behaviours that are planned, attitudes lead to intentions, which in turn lead to behaviours [46]. The theory has been supported in a wide variety of contexts outside of the entrepreneurship field [47], and represents the dominant approach to theorising about El because of its consistent and detailed specification $[48,49,50]$.

In SA, studies on El have mostly focused on university students in the commerce and management faculties, as these students are seen as a primary source of entrepreneurship [19, 51, 52, 53, 54, $55,56]$. These studies offer entrepreneurship education practitioners useful insights by focusing on entrepreneurship as a viable career option $[53,56]$ and in understanding how to reduce obstacles to graduate entrepreneurship [52].

Since there is an established and constantly evolving body of literature on El that is well-documented $[44,46,57,58]$, only the most recent findings are discussed to inform the formulation of the hypotheses. Recently, following an evidence-based approach to extending the pioneering work by Krueger et al. [46] - the first to compare and integrate the extant theories of intentions - Schlaegel and Koenig [59] meta-analytically tested and compared the TPB [45] and the entrepreneurial event model (EEM) [60]. These two are the most extensively tested competing theories that have been used to explain intentions [61]. Their findings challenge prior research, which assumed that perceived desirability includes attitudes and subjective norms, and that perceived feasibility includes self-efficacy and perceived behavioural control [59]. Moreover, although they found larger effect sizes for the EEM, it was the TPB that explained a greater amount of variance overall in El. The three antecedents of intentions have been extensively documented, and include the following [45]: (1) attitude refers to the individual's evaluation (favourable or unfavourable) of the target behaviour; (2) subjective norms capture the opinions of social reference groups (such as family and friends) about whether the individual should engage in the behaviour; and (3) perceived behavioural control denotes the perceived ease or difficulty of performing the behaviour. These three conceptually distinct antecedents of El, according to the TPB model - namely, attitude towards the behaviour (ATB), subjective norms (SN), and the perceived behavioural control (PBC) [45] - are briefly delineated below to indicate their underpinning of the formulation of the study's hypotheses.

\subsection{Attitude to the behaviour (ATB)}

ATB is the degree to which the implementation of a particular behaviour, such as starting a new business, is favourably or unfavourably valued [45]. This implies that ATB is formed by the individual's "expectations and beliefs about the personal impacts of expected outcomes resulting from the behaviour" - that is, behavioural beliefs [46]. Furthermore, the intensity of the belief is 
weighted by the evaluation of the outcomes [29]. ATB has been found in some studies to be the most important of the three predictors in the TPB [62], and the dominance of ATB over SN and PBC was reported in a South African study of graduate students [53, 54]. In the realm of academic entrepreneurship, a number of studies have investigated factors such as patenting, career experience, and educational background in determining scientists' propensity and attitudes to be entrepreneurial $[32,63,64,65]$. Against this backdrop of theoretical and empirical evidence, and in the first instance, it is hypothesised:

$\mathrm{H1}$ : There is no relationship between attitude towards behaviour as a distinct antecedent of intentions and entrepreneurial intentions among research scientists and engineers

\subsection{Subjective norms (SN)}

SN are the perceived social pressures to perform a particular behaviour, such as creating a business venture [45]. Thus SN is underpinned by what the individual perceives are the expectations and beliefs of influential people in his/her life about creating a start-up [43]. These influential people include the significant other, family, friends, colleagues, mentors, or role models [46]. A second aspect of SN is the individual's willingness to comply with these normative beliefs. The effect of the SN on El has varied substantially from one empirical study to another [66]. SN was found in some studies to be a poor predictor of El [46, 59], presumably as a result of the prevalence of student samples where normative beliefs are less relevant [67], while other studies have shown SN to have a strong effect on El [67]. Following these findings, and in line with the reasoning of including SN in the TPB model, it is anticipated:

$\mathrm{H}_{0}$ : There is no relationship between subjective norms as a distinct antecedent of intentions and entrepreneurial intentions among research scientists and engineers

\subsection{Perceived behavioural control (PBC)}

PBC refers to an individual's perceptions of his/her ability to execute a given behaviour [45]. It is governed by the beliefs about the perceived factors that facilitate or hinder execution of the behaviour - i.e., control beliefs [43]. The PBC construct is related to the entrepreneurial selfefficacy construct $[50,67]$, and both constructs are related to the perceived feasibility construct in the EEM [59]. Studies on entrepreneurial self-efficacy [68] and on learning orientation and passion for work [69] have been found to be significant determinants of El. Thus the PBC is postulated to exercise a larger role in $\mathrm{El}$ and in the decision to embark on an entrepreneurial path than ATB or SN [70]. Whereas entrepreneurial intention mediates the relationship between ATB, SN, PBC, and entrepreneurial behaviour, $\mathrm{PBC}$ also directly influences the subsequent entrepreneurial behaviour [67]. Consequently it is hypothesised:

$\mathrm{H}_{3}$ : There is no relationship between perceived behavioural control as a distinct antecedent of intentions and entrepreneurial intentions among research scientists and engineers

By merging the discourse on organisational support factors and institutional barriers, as gleaned from the literature, where differential effects on the antecedents of El have been reported [71], the following additional hypotheses are formulated:

$\mathrm{H}_{0}$ Perceived organisational support factors, in terms of university policies and incentives, organisational culture, entrepreneurship education, and networks will not influence entrepreneurial intentions through perceived behavioural control among research scientists and engineers

$\mathrm{H}_{0}$ : Perceived institutional barriers, in terms of capital availability, government regulations, and the national IP regime will influence entrepreneurial intentions through perceived behavioural control among research scientists and engineers

The hypothesised relationships are illustrated in Figure 1. The hypotheses and model structure are tested statistically in the sections that follow. 


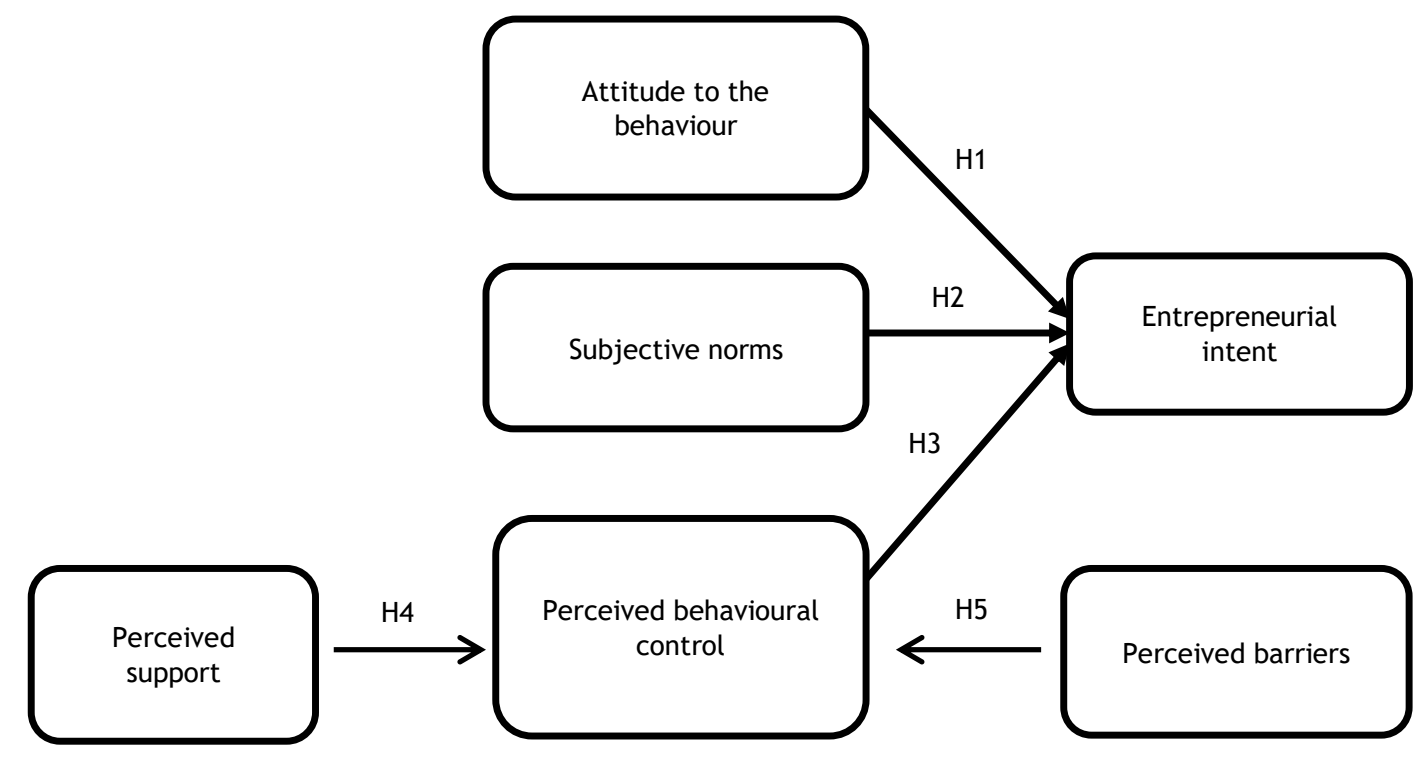

Figure 1: Research model with hypotheses

\section{RESEARCH DESIGN}

\subsection{Sampling and data collection}

The study draws on a sample of research scientists at universities and science councils in SA. SA's 26 public universities are distributed across all nine provinces of SA. The provinces with the three main metropolitan centres - namely, KwaZulu-Natal, Gauteng, and the Western Cape - are home to the largest number of universities. Prominent public South African universities include the University of Johannesburg, the University of Cape Town, North-West University, the University of KwaZulu-Natal, the University of Pretoria, the University of Stellenbosch, the University of Witwatersrand, Rhodes University, and the University of South Africa [72]. A science council is a statutory research body, of which there are eight in SA [1]. Their central purpose is to conduct directed research and development, and they are largely publicly-funded [73]. The science council selected for this study was the Council for Scientific and Industrial Research (CSIR) as it has national coverage, and has a long history of commercialisation of research outputs that pre-dates the formal establishment of technology transfer offices. The CSIR is also the largest research organisation in SA, if not the whole of Africa, where research, development, and innovation activities range from laboratory-scale validation to technology prototyping and pilot manufacture [74].

The survey population consisted of 1500 academic and research scientists and engineers in the faculties of science, technology, engineering, and medicine at three different and prominent (in terms of research outputs [72]) public universities in SA and at the CSIR during the survey period (August-October 2014). To ensure sufficient variability and a high regional representativeness, data was drawn from the three largest provinces in SA. It must be noted that the study examines university departments, rather than entire universities, since university-focused research neglects the fact that universities differ in the number and type of departments, with possibly different subcultures [75].

A written request was submitted to the relevant university and CSIR regional office to obtain the necessary permission for staff to participate and to administer the survey. The first mailing resulted in a response of 125 completed questionnaires, and was followed by a second and third email request to complete the on-line questionnaire, one week and three weeks later respectively. These efforts resulted in 156 additional responses. No patterns among undelivered surveys were noticed, as undelivered surveys were distributed approximately evenly among the different units/faculties, resulting in 247 full questionnaires. T-tests found no significant differences between the early and the late respondents in age, gender, institution type, and scientific field. 


\subsection{Instrument (refer to Appendix 1 for the full instrument)}

Entrepreneurial intention (EI): The study scales were based on the entrepreneurial intention questionnaire (EIQ) originally developed by Liñán and Chen [49]. The EIQ has been shown to display high internal reliability, with reported Cronbach's alpha values ranging from .77 to .94 for the EIQ's four factors (EI, ATB, SN, and PBC) [49, 71]. Moreover, the applicability of the EIQ has been empirically tested across cultures [76, 77]. It must be noted, however, that the EIQ does not explicitly distinguish between intentions to create start-ups for the commercialisation of research and those having other reasons, such as entrepreneurship outside the formal intellectual property system. Notwithstanding this caveat, the EIQ accurately reflects the TPB model constructs and the study hypotheses. Five of these 20 items were reverse statements (items $2,5,9,12,16$ ). Multi-item variables reduce potential measurement error [78]. The original EIQ was based on a seven-point Likert scale, where 1 = total disagreement and $7=$ total agreement. For the purpose of this study, a continuous rating scale was used in order to overcome the limited resolution of the Likert scale and to provide unequivocal interval data for the use of statistical methods that do not rely on the arithmetic mean [79]. By using such a continuous scale, the respondents were able to use a slider to indicate their selected position between 0 and 100 . The default position of the slider was set at 50 , requiring respondents to move the slider either to the left or to the right in accordance with the extent to which they agreed or disagreed with each of the scale items. Since Qualtrics was used as the on-line survey method, the respondents were prompted to answer all questions, and an answer was only registered when the slider was moved. This strategy ensured that all 27 scale items were answered, thus avoiding the problem of missing data.

Perceived organisational support: Perceived support was operationalised in terms of organisational support factors [1, 23, 24, 30, 80, 81, 82]. The measure included four academic entrepreneurshipspecific formative indicators: (1) university policies and incentives (item 27), (2) organisational culture (item 25), (3) entrepreneurship education and training (item 26), and (4) networks (item 24).

Perceived institutional barriers: Perceived institutional barriers were operationalised in terms of the following factors [32, 82, 83]. Two of the measures (items 21,22 ) related to capital availability and government regulations respectively, and the third (item 23) item related to the national IP regime.

Control variables: A number of individual-level factors that have been shown to affect El [71, 84] were accounted for in our study: Gender: Using the TPB, Santos and Liñán [30, 85] report that the El of females are lower than males, despite the similarity in the antecedent factors determining these intentions. Other studies show the extent of participation by women scientists in invention or technology disclosures to be lower than their male counterparts [71]. Age: Considering that in certain scientific fields the development of a commercially-ready technology may take years, older individuals will most likely be involved in start-ups [86]. However, other studies find that age makes no difference to El $[71,87]$. Scientific field: The propensity of scientists and academics to start a firm has been shown to vary widely from one scientific field to another [21, 87]. Such findings are consistent with the higher rate of patenting in the fields of engineering, information technology, and the life sciences or biotechnology [3,12]. These control variables were coded as follows: gender (dummy variables 1 = male, $0=$ female), age categories ( 21 to $30 ; 31$ to $40 ; 41$ to $50 ; 51$ to $60 ; 60+$ ), and scientific field (agricultural sciences; medical and life sciences; natural sciences; engineering and technology; and other).

\subsection{Data analysis}

To counter common-method bias, which affects item reliability and validity and/or the co-variation between two constructs [88], a number of procedural and statistical steps were taken to minimise the risk. Procedurally, the questionnaire featured a 'counter-balanced' question order, and the respondents were requested to be honest in their responses while assuring them of complete anonymity [88]. Moreover, a consistent scale format was used, where scale items that have been tried and tested were incorporated into the survey. The scale included negative and positive statements. Statistically, to ensure rigour in the results, all items relating to the constructs were explored in a single principal component analysis (PCA), using Harman's one-factor test. Results showed that three components with eigenvalues greater than 1.0 were detected, which accounted for 61 per cent of the variance. The largest component accounted for only 12 per cent. 
Consequently, no single factor accounted for the majority of the variance, and no evidence of common method bias was identified.

The reliability of the instruments was assessed using Cronbach's alpha [61] for internal consistency, and obtained satisfactory results: $\mathrm{El}=.93 ; \mathrm{ATB}=.87 ; \mathrm{SN}=.75 ; \mathrm{PBC}=.83$; perceived support factors $=.75$; perceived barriers $=0.69$ (considered as a borderline case). The inter-item correlations for each multi-item variable ranged from moderate to large, and seemed to fit together reliably. Thereafter the scales were aggregated by averaging the multi-item scores for each observation into a final variable score that was used in subsequent analyses.

\section{5}

RESULTS

Characteristics of the sample indicate that the majority of the responses (63 per cent) were from the CSIR, while 37 per cent of the respondents were from universities. In terms of field of specialisation, 53 per cent of the respondents were from engineering and technology, 26 per cent from natural sciences, 11 per cent from medical and health sciences, and three per cent from agricultural sciences, while seven per cent chose the 'other' category. More males (64 per cent) than females ( 36 per cent) responded. The largest proportion of the respondents ( 45 per cent) were in the age group 21 to 30 years old, 23 per cent were 31 to 40 years old, and 19 per cent were 41 to 50 years old, while 13 per cent were between 51 and 60 years old. Only two respondents were older than 60 years of age.

Comparisons of means tests were conducted to evaluate the effects of single control variables on EI in isolation from other control variables, with no significant results detected. Similarly, individual one-way ANOVA tests did not find any statistical differences in El between any of the control variables, except for one age grouping $(21-30), F(5,241)=2.97, p=0.0127$. Post hoc comparisons using the Tukey test confirmed that the mean El score for respondents aged 21 to 30 years $(M=$ $63.22, S D=24.93)$ was significantly larger than that of the age group 41 to 50 years $(M=49.18, S D=$ $24.74)$ and the age group 51 to 60 years $(M=47.02, S D=22.63), F(3,238)=6.22, p=.0004$. A plausible reason for higher levels of El in younger respondents, supported in past studies, is that older researchers already have an established research career and solid academic reputation, and are therefore less motivated than their younger colleagues to re-direct their focus to commercialisation [30].

Exploratory factor analysis (EFA) using the principal axis factoring with varimax rotation and Kaiser normalisation was used to assess the construct validity of the instrument. A solid overall MSA score of .94 was obtained, with no individual score being lower than .89. Based on the scree plot and the proportions of variation explained, a four-factor model was retained for the TPB model. Table 1(a) below shows the major factor loadings, having values $>.40$, for the final four-factor solution. In some instances cross-loadings were detected across factors. A closer look at the cross-loaded 'misplaced' variables reveals that these are all reverse-coded. This seems to indicate that respondents may have misread or misunderstood the reverse statements when completing the survey. Complex factor structures are one of the measurement problems that can arise from the use of reversed items [78]. However, none of the loadings was sufficiently low or negative to warrant removal of any of the scale items.

The same EFA procedure was conducted for the organisational support and institutional barrier factors. Table 1 (b) shows that the items are grouped into two separate factors, as expected, without any cross-loadings.

Table 1(a): Factor pattern loadings for El antecedents

\begin{tabular}{|c|c|c|}
\hline & Factor $1 \quad$ Factor 2 & Factor $3 \quad$ Factor 4 \\
\hline El5 & .82 & \\
\hline El4 & .79 & \\
\hline EI2 & .75 & \\
\hline El1 & .74 & \\
\hline
\end{tabular}


Table 1(a) (continues): Factor pattern loadings for El antecedents

\begin{tabular}{|c|c|c|c|c|}
\hline & Factor 1 & Factor 2 & Factor 3 & Factor 4 \\
\hline ATB5 & .69 & & & \\
\hline ATB4 & .69 & & & \\
\hline ATB2 & .66 & & & \\
\hline El6 & .66 & & & \\
\hline ATB1 & .51 & & & \\
\hline $\mathrm{PBC} 3$ & & .67 & & \\
\hline PBC1 & & .64 & & \\
\hline PBC4 & & .59 & & \\
\hline PBC6 & & .54 & & \\
\hline PBC5 & & .46 & .41 & \\
\hline ATB3 & & & .59 & \\
\hline PBC2 & & & .54 & \\
\hline EI3 & & .41 & .52 & \\
\hline SN2 & & & & .66 \\
\hline SN1 & & & & .62 \\
\hline SN3 & & & & .53 \\
\hline
\end{tabular}

Table 1(b): Factor pattern loadings for organisational support and institutional barriers

\begin{tabular}{lcr}
\hline & Factor 1 & Factor 2 \\
\cline { 2 - 3 } Perceived Sup4 & .72 & \\
Perceived Sup1 & .72 & \\
Perceived Sup2 & .59 & \\
Perceived Sup3 & .44 & \\
Perceived Bar1 & & .51 \\
Perceived Bar2 & & .37 \\
Perceived Bar3 & & .40 \\
\hline Note: Overall MSA $=.67$ &
\end{tabular}

Table 2 reports the means, standard deviations, and Pearson correlations. Similar to other studies, relatively moderate correlations between the antecedents of El were observed [47]. The correlation matrix provides no evidence of multicollinearity among the variables, as all the coefficients were within an acceptable range $(r=0.02$ to $r=0.78)$ and none of them exceeded the cut-off point of 0.85 [87]. These analyses provide evidence of discriminant validity.

Linear regression analyses were conducted to test the hypotheses. The regression was conducted in a stepwise manner in order to identify the most parsimonious subset of independent variables having the strongest relationship to $\mathrm{El}$, the dependent variable. In the first step, the linear regression focused on the effect of the proximal antecedent variables, ATB, SN, and PBC, on El. Table 3 shows an overall solid model fit, with $R^{2}=.77$ and a significant $F(276.42 ; p<0.001)$. While the $R^{2}$ provides an estimate of the strength of the relationship between the model and the response variable, it does not provide a formal hypothesis test for this relationship. Instead, the F-test of overall significance 
Table 2: Pearson's correlations and descriptive statistics

\begin{tabular}{lllllll}
\hline & 1 & 2 & 3 & 4 & 5 & 6 \\
1. EI & \multicolumn{7}{l}{1.00} & & & & & \\
2. ATB & $.78^{* * *}$ & 1.00 & & & & \\
3. SN & $.57^{* * *}$ & $.55^{* * *}$ & 1.00 & & & \\
4. PBC & $.65^{* * *}$ & $.64^{* * *}$ & $.46^{* *}$ & 1.00 & & \\
5. Barriers & -.02 & .03 & .07 & -.10 & 1.00 & \\
6. Support & $.14^{*}$ & .10 & $.23^{* * *}$ & $.24^{* *}$ & -.11 & 1.00 \\
Mean & 5.76 & 6.26 & 6.62 & 5.58 & 5.41 & 4.39 \\
Std. Dev. & 1.04 & 1.07 & 0.87 & 0.98 & 0.89 & 1.08 \\
\hline Note: ${ }^{*}=p<.05 ;{ }^{* *}=p<.01 ;{ }^{* * *}=p<.001$ & &
\end{tabular}

determines whether this relationship is statistically significant. An analysis of the variance inflation scores and the condition indices confirmed the absence of multicollinearity: highest VIF $=2.00$; highest condition index $=11.53$. The Durban Watson statistic of 2.06 and accompanying $p$ values of .63 and .36 indicated low to zero autocorrelation. Residual plots were normal and homoscedastic (not shown).

In the next step of the regression analysis, the distal variables of perceived organisational support and institutional barriers were included with the three proximal variables. These additional variables did not result in an improvement of variance explained $\left(R^{2}=.75\right)$. In the third step of the stepwise regression, the control variables were factored in with the distal and proximal variables. The control variables revealed relatively weak and non-significant effects on El, with an overall $\mathrm{R}^{2}=.72$. Lastly, a regression model for testing $\mathrm{H} 4 \mathrm{O}$ and $\mathrm{H} 5 \mathrm{O}$ in terms of perceived organisational support and institutional barriers influencing $\mathrm{El}$ through $\mathrm{PBC}$ (overall model $\mathrm{R}^{2}=0.13$ ) revealed a significant positive yet weak relationship between perceived organisational support and PBC $(B=0.25 ; p<$ $0.001)$, while there was a non-significant negative weak relationship for institutional barriers $(B=$. $0.10 ; p<0.15)$.

In summary, the regression results from model 1 in Table 3 revealed that ATB $(B=0.83 ; p<0.001)$ is the most important predictor of El, allowing for the rejection of null $\mathrm{H} 1 \mathrm{O}$, while $\mathrm{SN}(\mathrm{B}=0.15 ; \mathrm{p}<$ $0.001)$ and $P B C(B=0.20 ; p<0.001)$ - although having a small effect on $E I$ - are significant, and allow for the rejection of null $\mathrm{H} 2 \mathrm{O}$ and null $\mathrm{H} 3 \mathrm{O}$. Based on the results of the regression model incorporating perceived organisational support and institutional barriers influencing El through PBC, null $\mathrm{H} 4$ can be rejected, while null $\mathrm{H} 5 \mathrm{O}$ cannot be rejected.

Table 3: Regression results: Effect of antecedents on EI

\begin{tabular}{lccc}
\hline & \multicolumn{3}{c}{ Effect on El } \\
\cline { 2 - 4 } Intercept & B & 95\% confidence interval & B \\
\cline { 2 - 4 } ATB & $-19.16^{* * *}$ & -25.64 to -12.69 & .00 \\
SN & $.83^{* * *}$ & .73 to .92 & .72 \\
PBC & $.15^{* *}$ & .05 to .25 & .11 \\
$\mathrm{R}^{2}$ & $.20^{* *}$ & .09 to .32 & .14 \\
$\mathrm{R}^{2}$ adjusted & & .77 & \\
F & & .77 & \\
\hline Note: $\mathrm{B}=$ unstandardised effect, $\mathrm{B}=$ standardised effect: ${ }^{* *}=p<.01 ;{ }^{* * *}=p<.001$ \\
$* * *$
\end{tabular}


The empirical evidence emanating from this study successfully demonstrates the applicability of the antecedents for explaining El of the individual scientist, engineer, and academic researcher in the South African context. While intention models typically explain between 40 per cent and 60 per cent of the variance in El, the explanatory capacity of this study was much higher at 77 per cent. The sequence of the relative contributions of ATB, PBC, and SN corroborates the findings of previous studies [90], including those conducted in SA [53, 54].

Importantly, however, what sets the present results apart is the dominance of the ATB over both PBC and SN. Plausible reasons for these effects may be that awareness of, and exposure to, different aspects of entrepreneurship are likely to play an important role in shaping attitudes towards entrepreneurship [68]. Moreover, the relatively weak influence of SN and PBC on El was surprising. Some researchers consider PBC to be main determinant of EI, with ATB and SN playing supporting roles [70]. Prior studies [16] report that entrepreneurial self-efficacy, a construct closely related to $\mathrm{PBC}$, is more strongly related to $\mathrm{El}$ for growth-oriented businesses than to $\mathrm{El}$ for independenceorientated businesses. A possible explanation for the weaker effect of PBC is that this sample of scientists and engineers, with high levels of human capital, hold the belief that they will be able to acquire or access the skills necessary to start and run a business at the time it is required. In other words, PBC becomes important when engaging in the behaviour, and not when El are formed [19]. Even though SN was expected to play a bigger role in determining El [71], perhaps in the South African academic entrepreneurship context, where few research scientists have transitioned to entrepreneurship, there are as a result fewer significant others and role models who then inhibit normative beliefs, explaining the weak results for the SN-El link [19]. Similarly, other studies suggest that SN plays a lesser role than ATB and PBC in determining EI [46].

A counterintuitive finding of this study was that perceived institutional barriers do not have any significant effect on El or its antecedents. Notwithstanding measurement issues, it may be that the respondents perceive the existence of institutional barriers, such as onerous government regulations, as too arduous to navigate. The cost of regulatory compliance is extremely high in SA, especially for small businesses. It has been noted that the convergence of institutional risks, including crime, security, and corruption, along with dysfunctional government, poses challenges to potential and existing entrepreneurs in South Africa [41]. However, the significant relationship between organisational support factors and $\mathrm{El}$ is in line with past findings [81], which report a positive effect on El with educational programmes, as well as where university policies and incentives [28] positively affect El.

Practically, the implications of this study point to several areas of interest to entrepreneurs, educators, and policy makers. Implications for policy makers, encouraging entrepreneurship in emerging economies such as SA, are that the complexity of the antecedents involved in enhancing El should be given due consideration, without any one set of variables overshadowing the other factors. The interaction between ATB, SN, PBC, and El needs to be treated systematically. By integrating various predictors of El into one cohesive framework, as per the TPB model, policy makers may better understand the complementary nature of these different variables.

At several universities in SA, science and engineering are the priority foci, with a distinctive research role around the related concepts of 'technological innovation' and 'technology transfer' [19]. These developments are significant when considering that research suggests that entrepreneurship education has a greater effect on El for individuals from technological studies than from other areas of study [19]. Consequently, programmes designed to cater for scientists, engineers, and researchers are likely to be effective in facilitating El. Such programmes would require differentiated content - for example, patenting and regulatory approvals relevant to a specialised technical area - in order to promote the commercialisation of scientific research over independence or lifestyle entrepreneurship. Educators are also encouraged to highlight the advantages of starting one's own business - for example, by inviting successful entrepreneurs to share their experiences with the students and thus increase the levels of desirability to be entrepreneurial. Recognising that attitudes towards entrepreneurship are the main determinant in shaping $\mathrm{El}$, one way of improving attitudes is by providing inspiration through role models. Currently in SA, the education system does not lead to positive perceptions of personal feasibility and desirability as far as entrepreneurship is concerned, which has a negative impact on the size of the country's pool of intentional entrepreneurs [41]. Such 
low levels of entrepreneurial intentions are disconcerting when considering that well-educated individuals are capable of pursuing opportunity-based start-ups and creating high-quality businesses that are capable of creating many jobs [68].

\section{LIMITATIONS AND FUTURE RESEARCH}

This study is limited to the generic intention to start a new business, and does not distinguish between growth-oriented and independence-oriented ventures [14]. Moreover, the antecedents of the TPB are at the generic level of starting a business, while new venture creation includes multiple actions such as writing a business plan, raising start-up funding, etc. in its current form, the research instrument in this study was not designed to account for such specificity. The cross-sectional nature of the study does not allow for causality inferences to be made. Longitudinal studies are required to test whether El endure and can be positively linked to the actual behaviour of venture creation. Future research could investigate the role of institutions, their policies and practices, at a more granular level than the approach used in this study, where the limited number of generic support factors leaves scope for research on a more inclusive list of institutional barriers and organisational support factors. Future studies could adopt a multilevel lens to help illuminate different interactions between additional institutional and organisational-level factors that may affect El. Notwithstanding these limitations, this study provides fresh insights into the formation of El in the academic entrepreneurship and South African contexts.

\section{REFERENCES}

[1] Republic of South Africa. 2014. Proclamation by the President of the Republic of South Africa Number 43. Government Gazette Number 37817. Pretoria: Government Printer.

[2] DST. 2012. Ministerial Review Committee on Science, Technology and Innovation Landscape in South Africa: Final report. Pretoria: Government Printer.

[3] Alessandrini, M., Klose, K. \& Pepper, M.S. 2013. University entrepreneurship in South Africa: Developments in technology transfer practices. Innovation: Management, Policy and Practice, 15(2), pp. 205-214.

[4] Loise, V. \& Stevens, A.J. 2010. The Bayh-Dole Act turns 30. Science Translational Medicine, 2(52), $52 \mathrm{~cm} 27$.

[5] McDevitt, V.L., Mendez-Hinds, J., Winwood, D., Nijhawan, V., Sherer, T., Ritter, J.F. \& Sanberg, P.R. 2014. More than money: The exponential impact of academic technology transfer. Technology and Innovation, 16(1), pp. 75.

[6] Acs, Z.J., Autio, E. \& Szerb, L. 2014. National systems of entrepreneurship: Measurement issues and policy implications. Research Policy, 43(3), pp. 476-494.

[7] Beukman, E. \& Steyn, H. 2011. Phasing technology transfer projects for sustainable socio-economic development. The South African Journal of Industrial Engineering, 22(2), pp. 40-53.

[8] Rothaermel, F.T., Agung, S.D. \& Jiang, L. 2007. University entrepreneurship: A taxonomy of the literature. Journal of Industrial and Corporate Change, 16(4), 691-791.

[9] Sampat, B.N. 2009. The Bayh-Dole model in developing countries: Reflections on the Indian Bill on publicly funded intellectual property. Policy Brief: International Centre for Trade and Sustainable Development.

[10] Pouris, A. 2007. Technology transfer and diffusion: Capacity and potential in South Africa's public universities. Survey 2007: Higher Education South Africa.

[11] Pouris, A. 2012. Science in South Africa: The dawn of a renaissance? South African Journal of Science, 108(7/8), pp. 1-6.

[12] Sibanda, M. 2009. Intellectual property, commercialisation and institutional arrangements at South Africa's publicly financed research institutions, in D. Kaplan (ed.), The economics of intellectual property in South Africa, pp. 113-145. Geneva: World Intellectual Property Organisation.

[13] Uctu, R. \& Jafta, R. 2014. Spinning-off or licensing? The case of academic technology transfer at two South African universities. Industry and Higher Education, 28(2), pp. 127-141.

[14] Douglas, E.J. 2013. Reconstructing El to identify predisposition for growth. Journal of Business Venturing, 28(5), pp. 633-651.

[15] Urban, B. \& Heydenrych, J. 2015. Technology orientation and effectuation - links to firm performance in the renewable energy sector of South Africa. South African Journal of Industrial Engineering, 26(3), pp. 125-136.

[16] Bird, B. 1988. Implementing entrepreneurial ideas: The case for intention. Academy of Management Review, 13(3), pp. 442-453.

[17] Meyer, G.D. 2011. The reinvention of academic entrepreneurship. Journal of Small Business Management, 49(1), pp. 1-8.

[18] Bae, T.J., Qian, S., Miao, C. \& Fiet, J.0. 2014. The relationship between entrepreneurial education and El: A meta-analytic review. Entrepreneurship Theory and Practice, pp. 217-254. 
[19] Urban, B. \& Barreira, J. 2008. Insights into technopreneurship: Self-employment perceptions among engineering students. South African Journal of Higher Education, 21(5), pp. 567-583.

[20] Agarwal, R. \& Shah, S.K. 2014. Knowledge sources of entrepreneurship: Firm formation by academic, user and employee innovators. Research Policy, 43(7), pp. 1109-1133.

[21] Aldridge, T.T., Audretsch, D., Desai, S. \& Nadella, V. 2014. Scientist entrepreneurship across scientific fields. The Journal of Technology Transfer, 39(6), pp. 819-835.

[22] Audretsch, D. \& Kayalar-Erdem, D. 2005. Determinants of scientist entrepreneurship: An integrative research agenda. In S. Alvarez, R. Agarwal, \& O. Sorenson (eds), Handbook of entrepreneurship research 2, pp. 97-118: Springer US.

[23] Huyghe, A. \& Knockaert, M. 2015. The influence of organizational culture and climate on El among research scientists. The Journal of Technology Transfer, 40(1), pp. 138-160.

[24] Jain, S., George, G. \& Maltarich, M. 2009. Academics or entrepreneurs? Investigating role identity modification of university scientists involved in commercialization activity. Research Policy, 38(6), pp. 922-935.

[25] Stuart, T.E. \& Ding, W.W. 2006. When do scientists become entrepreneurs? The social structural antecedents of commercial activity in the academic life sciences. American Journal of Sociology, 112(1), pp. 97-144.

[26] Block, J.H., Thurik, R. \& Zhou, H. 2013. What turns knowledge into innovative products? The role of entrepreneurship and knowledge spillovers. Journal of Evolutionary Economics, 23, pp. 693-718.

[27] CSIR. 2012. CSIR entrepreneurs-in-residence model. Website: http://www.techtransfer.csir.co.za/wpcontent/uploads/2012/07/CSIR-Entrepreneurs-in-residence-EIR-brief-overview.pdf

[28] Nelles, J. \& Vorley, T. 2011. Entrepreneurial architecture: A blueprint for entrepreneurial universities. Canadian Journal of Administrative Sciences, 28(3), pp. 341-353.

[29] Ajzen, I. 2001. Nature and operation of attitudes. Annual Review of Psychology, 52, pp. 27-58.

[30] Prodan, I. \& Drnovsek, M. 2010. Conceptualizing academic-El: An empirical test. Technovation, 30(5-6), pp. 332-347.

[31] Karlsson, T. \& Wigren, C. 2012. Start-ups among university employees: The influence of legitimacy, human capital and social capital. The Journal of Technology Transfer, 37(3), pp. 297-312.

[32] Krabel, S. \& Mueller, P. 2009. What drives scientists to start their own company? An empirical investigation of Max Planck Society scientists. Research Policy, 38(6), 947-956.

[33] Rasmussen, E., Mosey, S. \& Wright, M. 2011. The evolution of entrepreneurial competencies: A longitudinal study of university spin-off venture emergence. Journal of Management Studies, 48(6), pp. 1314-1345.

[34] Sequeira, J., Mueller, S.L. \& Mcgee, J.E. 2007. The influence of social ties and self-efficacy in forming El and motivating nascent behavior. Journal of Developmental Entrepreneurship, 12(3), pp. 275-293.

[35] Djokovic, D. \& Souitaris, V. 2008. Spinouts from academic institutions: A literature review with suggestions for further research. Journal of Technology Transfer, 33(3), pp. 225-247.

[36] Goethner, M., Obschonka, M., Silbereisen, R.K. \& Cantner, U. 2009. Approaching the agora: Determinants of scientists' intentions to pursue academic entrepreneurship. Jena Economic Research Papers.

[37] Kolb, C. \& Wagner, M. 2014. Crowding in or crowding out: The link between academic entrepreneurship and entreprenuerial traits. The Journal of Technology Transfer, pp. 1-22.

[38] Kirby, D.A., Urbano, D. \& Guerrero, M. 2011. Making universities more entrepreneurial: Development of a model. Canadian Journal of Administrative Sciences, 28(3), pp. 302-316.

[39] KPMG \& SAVCA. 2014. KPMG and SAVCA venture capital and private equity industry performance survey of South Africa covering the 2013 calendar year. Johannesburg: KPMG and SAVCA.

[40] Griffiths, M.D., Kickul, J. \& Carlsrud, L. 2009. Government bureaucracy, transactional impediment, and El. International Small Business Journal, 27(5), pp. 626-645.

[41] Turton and Herrington. 2013. Global entrepreneurship monitor report South Africa. Cape Town: UCT.

[42] Pouris, A. \& Pouris, A. 2011. Patents and economic development in South Africa: Managing intellectual property rights. South African Journal of Science, 107(11/12), pp. 24-33.

[43] Ajzen, I. 2011. Theory of planned behavior. Website: http://people.umass.edu/aizen/tpb.html, accessed 18 September 2014.

[44] Liñán, F., Nabi, G. \& Krueger, N. 2012. British and Spanish entrepreneurial intentions: A comparative study. ReviSta de Economía Mundial, 33, pp. 73-103.

[45] Ajzen, I. 1991. The theory of planned behaviour. Organizational Behaviour and Human Decision Processes, 50, pp. 179-211.

[46] Krueger, N.F., Reilly, M.D. \& Carsrud, A.L. 2000. Competing models of El. Journal of Business Venturing, 15(5-6), pp. 411-432.

[47] Armitage, C.J. \& Conner, M. 2001. Efficacy of the theory of planned behaviour: A meta-analytic review. British Journal of Social Psychology, 40(4), pp. 471-499.

[48] Kolvereid, L. 1996. Prediction of employment status choice intentions. Entrepreneurship Theory and Practice, 21(1), pp. 47-57.

[49] Liñán, F. \& Chen, Y.-W. 2009. Development and cross-cultural application of a specific instrument to measure El. Entrepreneurship Theory and Practice, 33(3), pp. 593-617.

[50] Van Gelderen, M., Brand, M., van Praag, M., Bodewes, W., Poutsma, E. \& Van Gils, A. 2008. Explaining El by means of the theory of planned behaviour. Career Development International, 13(6), pp. 538-559. 
[51] Farrington, S.M., Venter, D.J.L. \& Neethling, A. 2012. Entrepreneurial attributes and intentions: Perceptions of South African business science students. Management Dynamics, 21(3), pp. 17-32.

[52] Fatoki, 0. 2010. Graduate entrepreneurial intention in South Africa: Motivations and obstacles. International Journal of Business and Management, 5(9), pp. 87-98.

[53] Gird, A. \& Bagraim, J.J. 2008. The theory of planned behaviour as predictor of entrepreneurial intent amongst final-year university students. South African Journal of Psychology, 38(4), pp. 711-724.

[54] Malebana, J. 2014. El of South African rural university students: A test of the theory of planned behaviour. Journal of Economics and Behavioral Studies, 6(2), pp. 130-143.

[55] Muofhe, N.J. \& Du Toit, W.F. 2011. Entrepreneurial education's and entrepreneurial role models' influence on career choice. SA Journal of Human Resource Management, 9, pp. 1-15.

[56] Viviers, S., Solomon, G. \& Venter, C. 2013. El and behaviours of South African university students. South African Journal of Entrepreneurship and Small Business Management, 6, pp. 1-20.

[57] Boyd, N.G. \& Vozikis, G.S. 1994. The influence of self-efficacy on the development of entrepreneurial intentions and actions. Entrepreneurship Theory \& Practice, 18(4), pp. 63-78.

[58] Engle, R.L., Dimitriadi, N., Gavidia, J.V., Schlaegel, C., Delanoe, S., Alvarado, I., He, X., Buame, S. and Wolff, B. 2010. Entrepreneurial intent: A twelve-country evaluation of Ajzen's model of planned behavior. International Journal of Entrepreneurial Behavior \& Research, 16(1), pp. 35-37.

[59] Schlaegel, C. \& Koenig, M. 2014. Determinants of entrepreneurial intent: A meta-analytic test and integration of competing models. Entrepreneurship Theory and Practice, 38(2), pp. 291-332.

[60] Shapero, A. 1982. Social dimensions of entrepreneurship, in C. Kent, D. Sexton \& K. Vesper (eds), The Encyclopedia of Entrepreneurship. Englewood Cliffs: Prentice Hall.

[61] Shook, C.L., Priem, R.L. \& McGee, J.E. 2003. Venture creation and the enterprising individual: A review and synthesis. Journal of Management, 29(3), pp. 379-399.

[62] Aldridge, T.T. \& Audretsch, D. 2011. The Bayh-Dole Act and scientist entrepreneurship. Research Policy, 40(8), pp. 1058-1067.

[63] Ferreira, J.J., Raposo, M.L., Rodrigues, R.G., Dinis, A. \& do Paço, A. 2012. A model of entrepreneurial intention: An application of the psychological and behavioral approaches. Journal of Small Business and Enterprise Development, 19(3), pp. 424-440.

[64] Fritsch, M. \& Krabel, S. 2010. Ready to leave the ivory tower? Academic scientists' appeal to work in the private sector. The Journal of Technology Transfer, 37(3), pp. 271-296.

[65] Goel, R.K., Göktepe-Hultén, D. \& Ram, R. 2015. Academics' entrepreneurship propensities and gender differences. The Journal of Technology Transfer, 40(1), pp. 161-177.

[66] Heuer, A. \& Liñán, F. 2013. Testing alternative measure of subjective norms in entrepreneurial intention models. International Journal of Entrepreneurship and Small Business, 19(1), pp. 35-50.

[67] Kautonen, T., Van Gelderen, M. \& Fink, M. 2013. Robustness of the theory of planned behavior in predicting El and actions. Entrepreneurship Theory and Practice, early view, pp. 1-20.

[68] Urban, B. 2012. A metacognitive approach to explaining El. Management Dynamics, 21(2), pp. 16-33.

[69] De Clercq, D., Honig, B. \& Martin, B. 2013. The roles of learning orientation and passion for work in the formation of entrepreneurial intention. International Small Business Journal, 31(6), pp. 652-676.

[70] Autio, E., Keeley, R.H., Klofsten, M., Parker, G.G.C. \& Hay, M. 2001. Entrepreneurial intent among students in Scandinavia and in the USA. Enterprise and Innovation Management Studies, 2(2), pp. 145-160.

[71] Goethner, M., Obschonka, M., Silbereisen, R.K. \& Cantner, U. 2012. Scientists' transition to academic entrepreneurship: Economic and psychological determinants. Journal of Economic Psychology, 33(3), pp. 628-641.

[72] Universities SA. 2016. Website: http://www.universitiessa.ac.za/public-universities-south-africa.

[73] Scholes, R.J., Anderson, F., Kenyon, C., Napier, J., Ngoepe, P., van Wilgen, B. \& Weaver, A. 2008. Science councils in South Africa. South African Journal of Science, 104, pp. 435-438.

[74] CSIR. 2013. CSIR 2012/2013 annual report Pretoria: CSIR.

[75] Walter, S.G., Parboteeah, K.P. \& Walter, A. 2013. University departments and self-employment intentions of business students: A cross-level analysis. Entrepreneurship Theory and Practice, 37(2), pp.175-200.

[76] lakovleva, T., Kolvereid, L. \& Stephan, U. 2011. El in developing and developed countries. Education \& Training, 53(5), pp. 353-370.

[77] Liñán, F., Urbano, D. \& Guerrero, M. 2011. Regional variations in entrepreneurial cognitions: Start-up intentions of university students in Spain. Entrepreneurship \& Regional Development, 23(3-4), pp. 187215.

[78] Weijters, B. \& Baumgartner, H. 2012. Misresponse to reversed and negated items in surveys: A review. Journal of Marketing Research, 49(5), pp. 737-747.

[79] Treiblmaier, H. \& Filzmoser, P. 2011. Benefits from using continuous rating scales in online survey research. Paper presented at the International Conference on Information Systems, Shanghai, China.

[80] Rasmussen, E. 2008. Government instruments to support the commercialization of university research: Lessons from Canada. Technovation, 28(8), pp. 506-517.

[81] Souitaris, V., Zerbinati, S\& Al-Laham, A. 2007. Do entrepreneurship programmes raise entrepreneurial intention of science and engineering students? The effect of learning, inspiration and resources. Journal of Business Venturing, 22(4), pp. 566-591.

[82] Liuthje, C. \& Franke, N. 2003. The 'making' of an entrepreneur: Testing a model of entrepreneurial intent among engineering students at MIT. R\&D Management, 33(2), pp. 135-147. 
[83] De Bettignies, J.-E. \& Brander, J. 2007. Financing entrepreneurship: Bank finance versus venture capital. Journal of Business Venturing, 22(6), pp. 808-832.

[84] Ding, W.W., Murray, F. \& Stuart, T.E. 2006. Gender differences in patenting in the academic life sciences. Science, 313(5787), pp. 665-667.

[85] Santos, F.J. \& Liñán, F. 2010. Gender differences in El: An international comparison: Working paper. Sevilla, Spain: Departamento Economía Aplicada I, Universidad de Sevilla.

[86] Toole, A.A. \& Czarnitzki, D. 2010. Commercializing science: Is there a university "brain drain" from academic entrepreneurship? Management Science, 56(9), pp. 1599-1614.

[87] Goel, R.K. \& Grimpe, C. 2012. Are all academic entrepreneurs created alike? Evidence from Germany. Economics of Innovation and New Technology, 21(3), pp. 247-266.

[88] Podsakoff, P.M., MacKenzie, S.B. \& Podsakoff, N.P. 2012. Sources of method bias in socail science research and recommendations on how to control it. Annual Review of Psychology, 63, pp. 539-569.

[89] Fornell, C. \& Larcker, D.F. 1981. Evaluating structural equation models with unobservable variables and measurement error. Journal of Marketing Research, 18(2), pp. 39-50.

[90] Moriano, J.A., Gorgievski, M., Laguna, M., Stephan, U. \& Zarafshani, K. 2012. A cross-cultural approach to understanding entrepreneurial intention. Journal of Career Development, 39(2), pp. 162-185. 